\title{
Cold-Pad-Batch Bio-Pretreatment of Cotton Woven Fabrics: A Case Report on Industrial Trials
}

\author{
Eun Kyung Choe ${ }^{1 *}$, Juhea Kim ${ }^{1}$ and Sung Dong Kim² \\ ${ }^{1}$ Textile Materials Division, Korea Institute of Industrial Technology, Korea \\ ${ }^{2}$ Department of Organic and Nano System Engineering, Konkuk University, Korea
}

Submission: October 20, 2017; Published: December 13, 2017

*Corresponding author: Eun Kyung Choe, Textile Materials Division, Korea Institute of Industrial Technology, 143 Hanggaul-ro, Sangrok-gu, Ansan-15588, Korea, Tel: 82-31-8040-6211; Email: ekchoe@kitech.re.kr

\begin{abstract}
In spite of technologically proved bioscouring using pectinase that substitutes for conventional alkaline scouring, the batch-wise bioscouring in a single bath is sometimes not welcome to certain companies where continuous or cold-pad-batch alkaline pretreatment for cotton woven fabrics used to be done with pad steamer or pad-batch equipments because of low productivity of single batch-wise process as well as the company's existing unique facility. To increase the applicability of enzymatic bioscouring, two industrial trials of bio-pretreatment by cold-padbatch method were carried out in two different sites using their own pad-batch facilities. Simultaneous enzymatic desizing and scouring for cotton and cotton-blend woven fabrics were carried out using amylase of low-temperature type and alkaline pectinase with $100 \%$ cotton woven fabric of 200 yard length and cotton/nylon/polyurethane woven fabric of 1000 yard length by the cold-pad-batch method. Padding solution was prepared by mixing amylase, alkaline pectinase and wetting agent where $\mathrm{pH}$ is adjusted to 8.5 using sodium carbonate. Absorbance of treated fabric was good enough for dyeing and uniform when absorbance at five locations across the length of 1000 yards were measured. Results were compared with those of each company's conventional cold-pad-batch chemical pretreatment. When conventional bleaching is done after simultaneous desizing and scouring in cold-pad-batch method using two enzymes, absorbance and whiteness is as excellent as the company's conventional method.
\end{abstract}

Keywords: Cold-pad-batch; Pretreatment; Bio-pretreatment; Desizing; Scouring; Bioscouring; Enzymatic; Alkaline; Cotton; Cotton blend

\section{Introduction}

The noncellulosic constituents of cotton fiber are known to be waxes, pectins, hemicellulose, proteins, and mineral matters ranging from 4 to $12 \%$ of the dry fiber weight and to be located mostly in the cuticle, in the primary cell wall, and in the lumen.

Natural cotton wax of 0.4 to $1.0 \%$ serves as a protective barrier to water penetration comprising the cuticle on the outer surface of the fiber while pectins of $0.7-1.2 \%$ are present as a poly-Dgalacturonic acid in the form of insoluble salts of $\mathrm{Ca}, \mathrm{Mg}$, and Fein the primary cell wall underlying the waxy cuticle $[1,2]$.

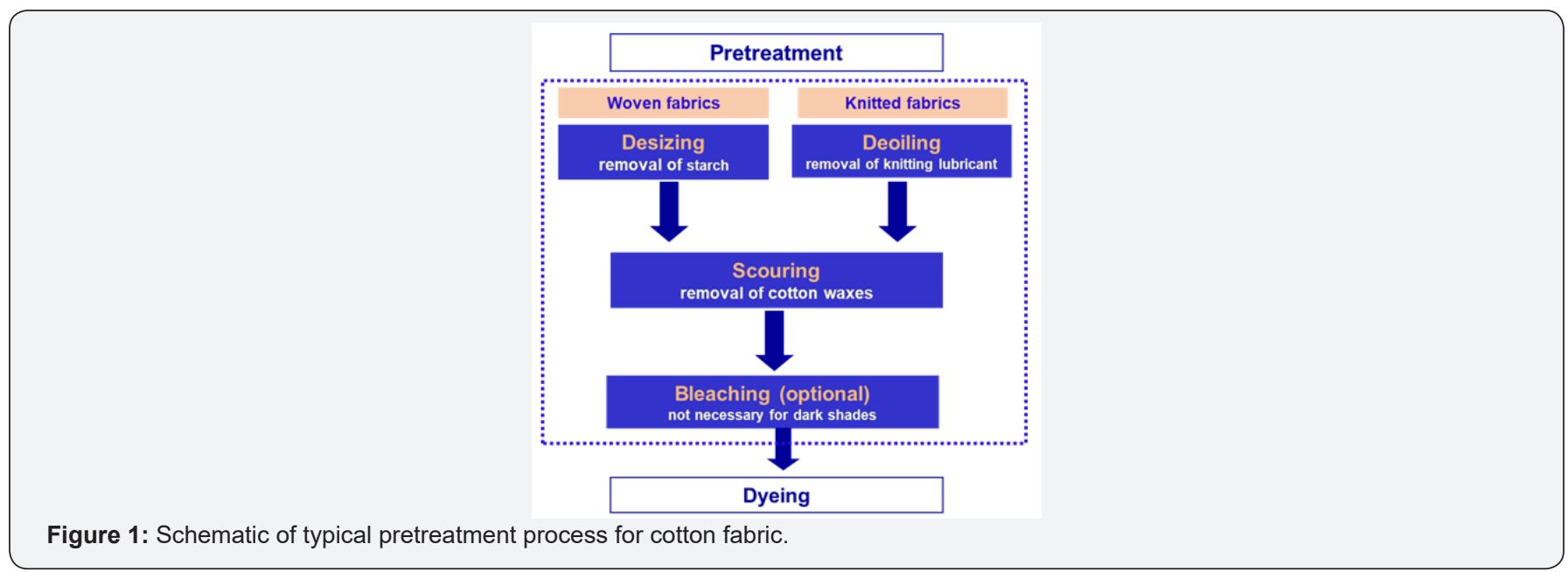


reproducible high quality results in dyeing of cotton fabrics, pretreatment process is required to reduce impurities sufficiently to improve cotton fabric wettability (Figure 1). Besides natural impurities such as wax and pectins of which removal is essential [3], removal of secondary added impurities are also important. In the case of cotton knitted fabrics, the added chemicals are those lubricants, for example, paraffin waxes used in spinning the yarn and on the knitting machine that comprise about 0.5 - $2 \%$ of fabric weight $[4,5]$ and are removed in scouring process together with natural cotton wax. For cotton woven fabrics, a separate enzymatic desizing process has been carried out traditionally to remove starch-based sizes added on warp yarns about $15 \%$ of the yarn weight in weaving [6] while synthetic sizes applied to man-made fibers are generally water soluble and can be removed in scouring process [2].

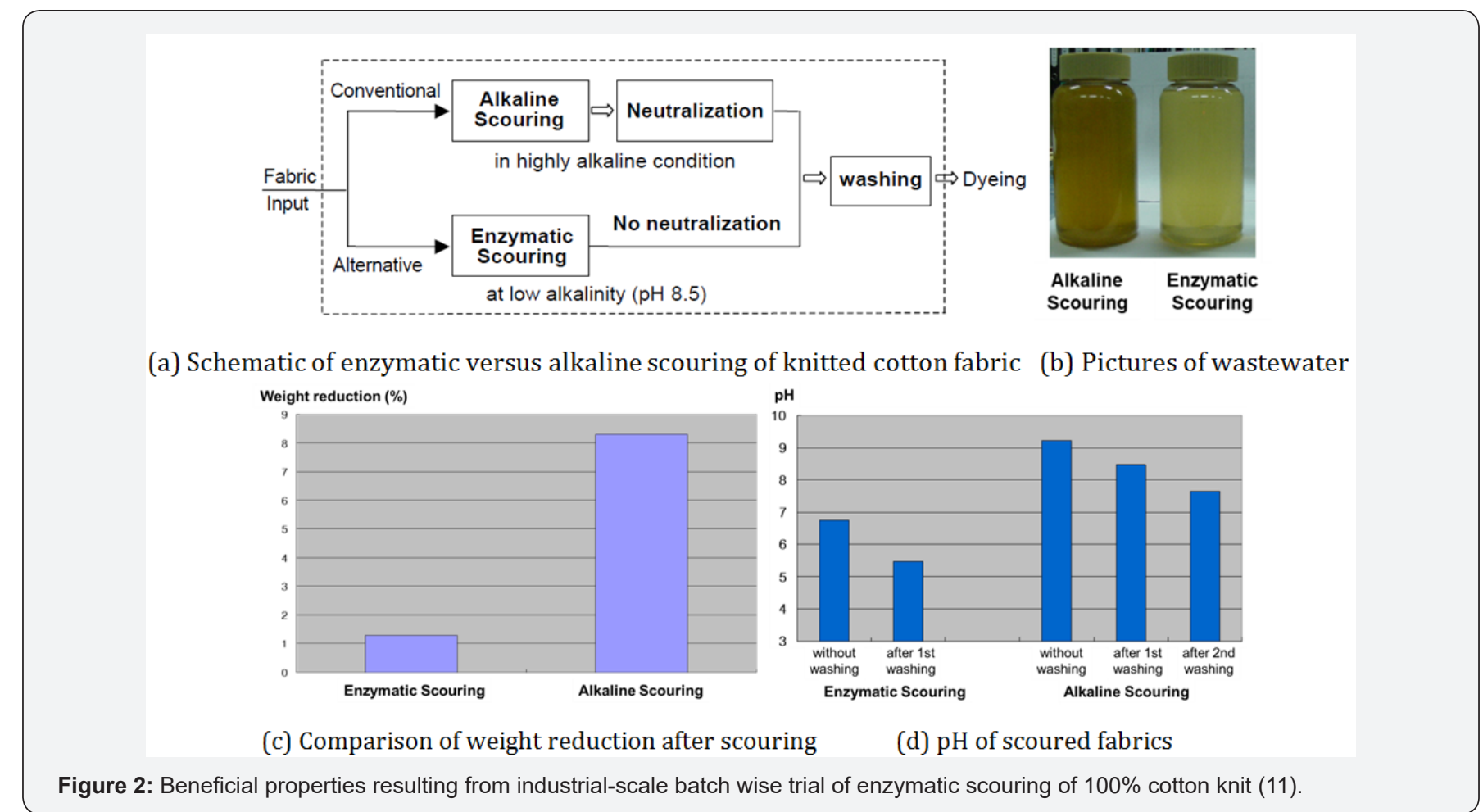

The conventional alkaline pretreatment process has been replaced with environment friendly approach using different enzymes. For examples, amylases for removing starch-based sizing and cellulases for denim-washing and biopolishing were introduced in the1960s and in the1980s, respectively while pectinase for cotton scouring was launched in the 2000s [3,6$10]$. Because pectin acts as glue in the primary cell wall of cotton fibers, the different components present in the primary cell wall layer can be removed easily in a subsequent washing procedure after enzymatic destabilization of the pectin structure [8]. According to (Figure 2(a)), neutralization can be omitted in bioscouring and effluent from alkaline scouring is darker than from bioscouring. In addition to lower loss in weight (Figure 2(b)) and lower pH of scoured fabrics (Figure 2(c)), other beneficial properties from bioscouring using pectinase have been reported to be softer handle, reduction of chemical load to environment and energy consumption as well as lower pilling tendency due to lower damage to fiber (Figure 2(d)) when compared to alkaline scoured fabrics [3,10-13]. Combined bioscouring and biopolishing as well as combined desizing and bioscouring in one step have been also proposed [10].
Cold-pad-batch equipment for pretreatment and dyeing consists of a pad mangle, a means of winding fabric onto a roll and washing chambers with advantages of much reduced water consumption, relatively low cost of equipment, higher productivity over a single batch wise equipment such as a jet dyeing machine $[14,15]$. However, textile dyeing companies that are equipped with cold-pad-batch machines and run their conventional cold-pad-batch alkaline pretreatment are faced with the difficulty to introduce the new technology in spite of knowing that batch wise enzymatic scouring is successfully implemented. The aim of this case study is to try enzymatic coldpad-batch bio-pretreatment using the equipment of industrial sites and compared its performance with the company's conventional cold-pad-batch alkaline chemical pretreatment.

\section{Case Report}

\section{Materials}

Two kinds of cotton woven fabrics were used and characteristics of each fabric were presented in Table 1 . Chemicals such as $\mathrm{NaOH}(50 \%)$, sodium carbonate and hydrogen peroxide $(35 \%)$ were all industrial grade. Company-specific wetting agent 
(DGA-W15, Actiron AT-2), scouring agent, oxidative desizing agent, and $\mathrm{H} 2 \mathrm{O} 2$ stabilizer were used in the company's chemical pretreatment. Enzymes were Aquazyme 240L and Scourzyme L from Novozymes.

Table 1: Characteristics of fabrics used

\begin{tabular}{|c|c|c|c|c|c|}
\hline Fabrics & Fiber Composition & Weave Type & Yarn Number & $\begin{array}{c}\text { Fabric } \\
\text { Weight(g/m² }\end{array}$ & $\begin{array}{c}\text { Amounts Treated / } \\
\text { Company Name }\end{array}$ \\
\hline Industrial Trial No1 & $100 \%$ Cotton & Plain weave & Ne=20 & $\begin{array}{c}200 \text { yards / } \\
\text { K Textile Co., Ltd }\end{array}$ \\
\hline Industrial Trial No2 & $\begin{array}{c}60 \% \text { Cotton } \\
40 \% \text { Nylon \& PU }\end{array}$ & Satin weave & $\begin{array}{c}\text { Warp: Ne=40 } \\
\text { Weft: Nylon 140 D / } \\
\text { PU 40 D }\end{array}$ & 223 & $\begin{array}{c}1000 \text { yards / } \\
\text { CW Textile Co., Ltd. }\end{array}$ \\
\hline
\end{tabular}

\section{Industrial trials of Cold-Pad-Batch pretreatment}

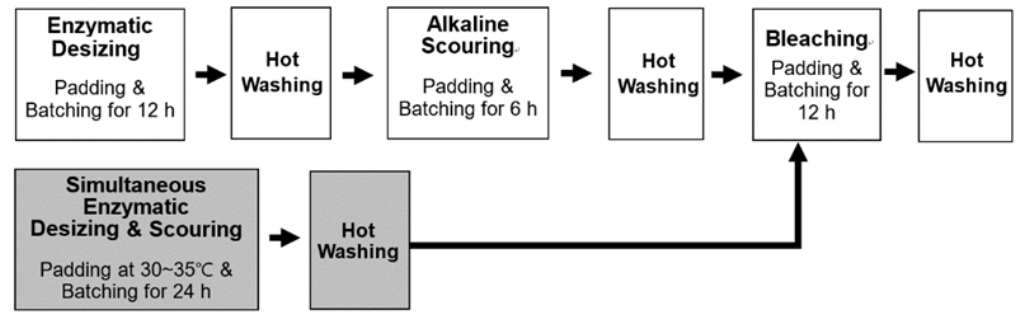

(a) Industrial Trial No.1 (100\% Cotton woven).

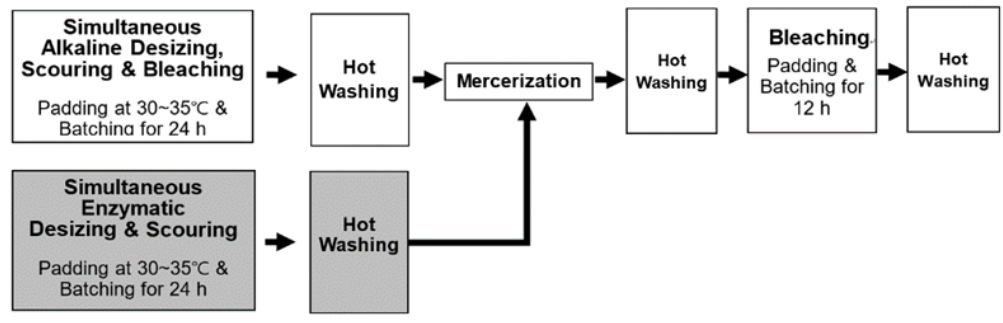

(b) Industrial Trial No.2 (Cotton-blend woven).

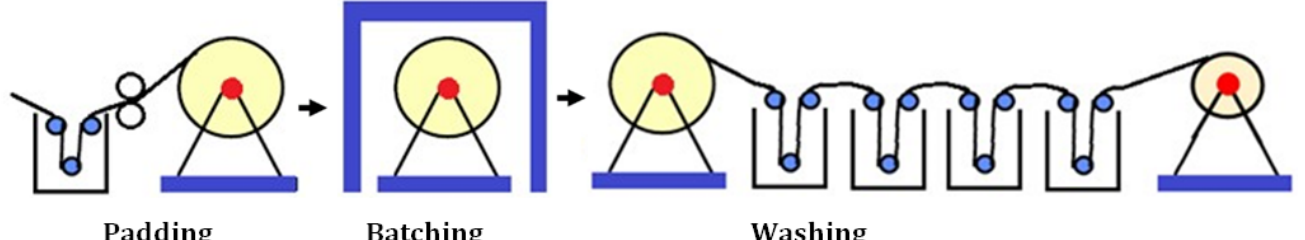

(c) Images of cold-pad-batch process.

Figure 3: Schematics of conventional (white boxes) and enzymatic (greyboxes) cold-pad-batch pretreatments for (a) cotton and (b) cottonblend woven fabrics tried in two dyeing companies and (c) images of cold-pad-batch process.

The first CPB bio-pretreatment was tried with $100 \%$ cotton woven fabric of 200 yards in one company where the company's CPB alkaline pretreatment was carried out according to (Figure $3(\mathrm{a})$ ). The second CPB bio-pretreatment was run with cottonblend woven fabric of 1000 yards in another company according to the process schematized in (Figure 3(b)). For comparisons, each company's conventional pretreatment was carried out with the same cotton fabric as used in bio-pretreatment. (Figure 3(c)) shows the overall view of the cold-pad-batch process done in two companies.

The CPB bio-pretreatment was carried by padding, batching and washing with hot water in a four-box washer. The details for CPB bio-pretreatment were as followings: 
- Padding solution: Aquazyme 3g/L, Scourzyme 6g/L, Wetting agent $3 \mathrm{~g} / \mathrm{L}$, pH 8.5

- Padding at $30-35^{\circ} \mathrm{C}$

- Pick-up rate: $85 \%$

- Batching for $24 \mathrm{~h}$ at room temperature

- Hot washing using a continuous four-box washer :

1st box $\left(95{ }^{\circ} \mathrm{C}\right.$, emusifier $\left.2 \mathrm{~g} / \mathrm{L}\right), 2$ nd box $\left(95^{\circ} \mathrm{C}\right)$, 3rd box $\left(80{ }^{\circ} \mathrm{C}\right), 4$ th box $\left(60{ }^{\circ} \mathrm{C}\right)$

The first box contained emulsifying agent to wash out enzymatically degraded pectins and other impurities that came out together. Sodium carbonate $\left(\mathrm{Na}_{2} \mathrm{CO}_{3}\right)$ was used for $\mathrm{pH}$ adjustment of enzyme padding solution. Because the temperature of padding and batching was about room temperature, amylase of low-temperature type was chosen because it was proved to be more effective than amylase of high-temperature type and importance of removal of sizing agent for enzymatic scouring performance was reported [16].

The second company's conventional simultaneous alkaline desizing, scouring and bleaching carried out as followings:

- Padding solution: Oxidative desizing agent $1 \mathrm{~g} / \mathrm{L}$, wetting agent $2 \mathrm{~g} / \mathrm{L}$, scouring agent $10 \mathrm{~g} / \mathrm{L}, \mathrm{NaOH}$ (50\%) 100g/L, $\mathrm{H}_{2} \mathrm{O}_{2}(35 \%) 70 \mathrm{~g} / \mathrm{L}, \mathrm{H} 2 \mathrm{O} 2$ stabilizer $10 \mathrm{~g} / \mathrm{L}$

- Pick-up rate: $85 \%$

- Batching for $24 \mathrm{~h}$ at room temperature

\section{Measurements}

Treated fabrics were conditioned and subjected to water drop test. A round fabric sample with a diameter of $10 \mathrm{~cm}$ was cut and mounted on the test plate of Gravimetric Absorbency Testing System (GATS, M/K Systems, Inc. USA) where absorbed weight per gram of fabric sample was recorded every $0.4 \mathrm{sec}$ for $10 \mathrm{sec}$. Additional water absorbency test was carried with all fabric samples according to the AATCC water drop test (test method TS-018) and time for absorbing a water drop was measured. Colored aqueous solution of $1 \%$ direct blue dye was additionally used for drop test on cotton-blend fabric. Color measurements of treated fabrics were taken with Macbeth Color Eye 3000 using D65 daylight as the illuminant. Whiteness, L-value and b-value were measured.

\section{Results \& Discussion}

Performance of pretreatment is evaluated mainly by water absorbance of treated fabrics. When absorbance data were compared in (Figure 4(a)), 100\% cotton woven fabrics obtained by two different CPB pretreatments resulted in the almost same absorbance between the simultaneous enzymatic desizing and scouring and the enzymatic desizing followed by alkaline scouring. Both new CPB bio-pretreatment and the company's conventional alkaline pretreatment were tried with cotton fabric in industrial scale of 200 yards. With the company's CPB equipment according to Industrial Trial No.1 presented in (Figure 4(b)) where both pretreatments contained CPB bleaching at the end.
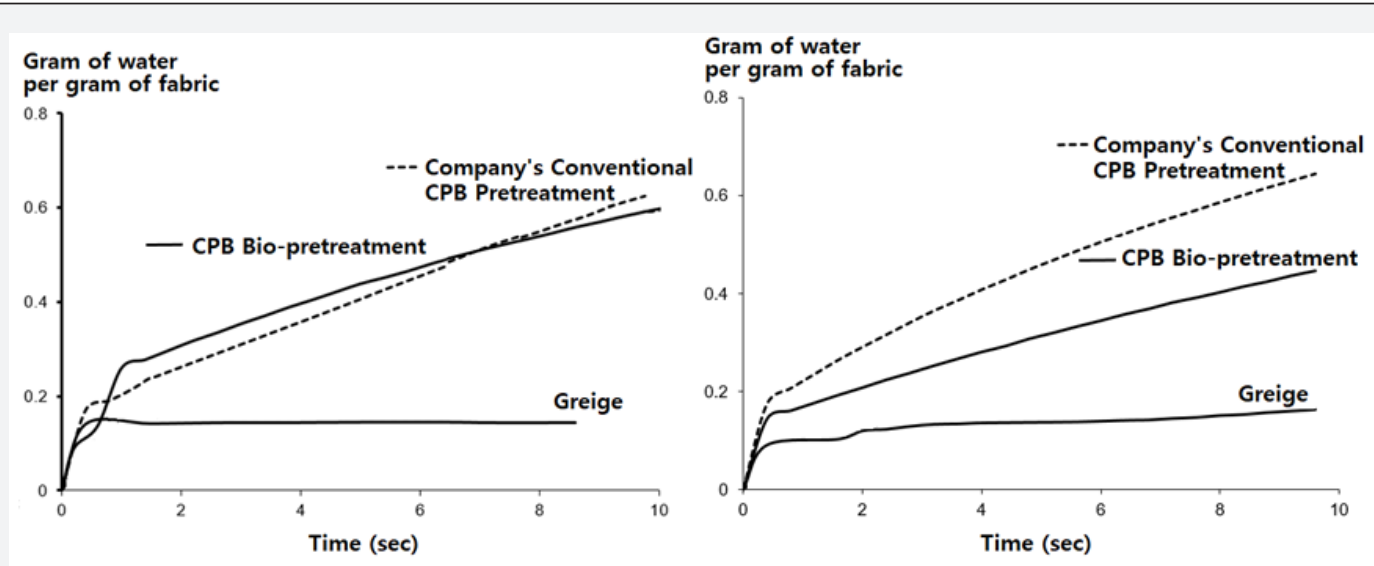

(a) Industrial Trial No.1 (100\% Cotton woven) (b) Industrial Trial No.2 (Cotton-blend woven)

Figure 4: Absorbance measurement of (a) 100\% cotton woven (Industrial Trial No.1) and (b)cotton-blend woven(Industrial Trial No.2) fabrics pretreated by cold-pad-batch method according to enzymatic and companies' conventional chemical processes.

When the simultaneous enzymatic desizing and scouring by CPB was tried in the other company with cotton-blend fabrics, absorbance data by GATS revealed that cotton-blend fabric after CPB bio-pretreatment absorbed less water than after the second company's conventional pretreatment in which the simultaneous alkaline desizing, scouring and bleaching by CPB was carried out (Figure 4(b). However, the drop test on cotton blend fabric obtained by CPB bio-pretreatment was less than 3 seconds that is regarded to satisfy the absorbency standard for drop test that AATCC (American Association of Textile Chemists and Colorists) recommends to be in the range of 1 to $5 \mathrm{sec}$. All other fabrics were wetted in less than 2 seconds by drop tests. 
The cotton-blend fabric used in industrial trial No.2 consisted of the warp yarn of $100 \%$ cotton and the weft yarn of $60 \%$ nylon and $40 \%$ polyurethane. Therefore, CPB bio-pretreatment seemed to remove less impurities on the weft yarn than the company's CPB chemical pretreatment while CPB bio-pretreatment worked very well on $100 \%$ cotton warp yarn as evidenced by drop test results (Figure 5(a)). In this industrial trial No.2 where the treated cotton blend fabric was 1000 yards in length, absorbance data measured in the spot of 100, 450, 680, 900 and 1000 yards proved the homogeneous treatment by CPB bio-pretreatment across the long length (Figure $5(\mathrm{~b})$ ).

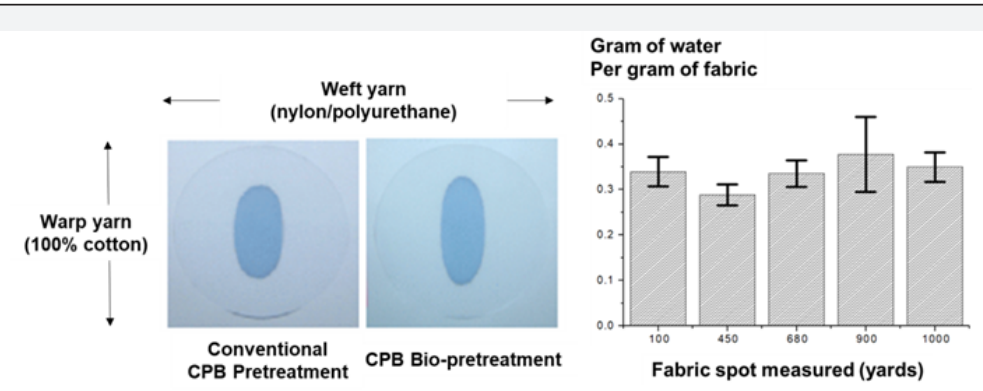

(a) Drop test on pretreated fabric (b) Water absorbance measurement on CPB Bio-pretreated fabric by GATS.

Figure 5: Absorbance measurement on cotton/nylon/polyurethane woven fabric (Industrial Trial No.2) by (a) drop test and (b) gravimetric absorbency testing system (GATS) showing the homogeneous results across the 1000 yards of fabric pretreated by simultaneous enzymatic cold-pad-batch desizing and scouring(arrow bar : $n=5)$.

Table 2: Evaluation of whiteness, lightness and b-value of cold-pad-batch pretreated fabrics.

\begin{tabular}{|c|c|c|c|c|c|c|c|c|}
\hline & \multicolumn{2}{|c|}{ Fabrics pretreated by } & \multirow{2}{*}{\multicolumn{2}{|c|}{ Whiteness }} & \multirow{2}{*}{\multicolumn{2}{|c|}{$\mathbf{L}$}} & \multirow{2}{*}{\multicolumn{2}{|c|}{$\mathbf{b}$}} \\
\hline & $\begin{array}{c}\text { Enzymatic } \\
\text { CPB pretreatment }\end{array}$ & $\begin{array}{l}\text { Company's Chemical } \\
\text { CPB pretreatment }\end{array}$ & & & & & & \\
\hline \multirow{4}{*}{ Industrial Trial No.1 } & \multicolumn{2}{|c|}{ Greige } & 8.6 & & 85.5 & & 11.7 & \\
\hline & \multirow{2}{*}{$\begin{array}{l}\text { Simultaneous } \\
\text { enzymatic desizing \& scouring }\end{array}$} & \multirow{2}{*}{$\begin{array}{l}\text { Enzymatic desizing \& } \\
\text { alkaline scouring in two steps }\end{array}$} & 11.2 & 15.7 & 83.7 & 84.9 & 10.1 & 10 \\
\hline & & & & & & & & \\
\hline & \multicolumn{2}{|c|}{$\mathrm{H}_{2} \mathrm{O}_{2}$-bleaching } & 67.8 & 63.7 & 93.7 & 89.4 & 2 & 2.4 \\
\hline \multirow{4}{*}{ Industrial Trial No.2 } & \multicolumn{2}{|c|}{ Greige } & 43.9 & & 89.7 & & 6.6 & \\
\hline & $\begin{array}{c}\text { Simultaneous } \\
\text { enzymatic } \\
\text { desizing \& scouring }\end{array}$ & $\begin{array}{c}\text { Simultaneous } \\
\text { alkaline desizing, scouring \& } \\
\text { bleaching }\end{array}$ & 50.7 & 72.8 & 89.8 & 91.9 & 5.3 & 1.6 \\
\hline & \multicolumn{2}{|c|}{ Mercerized } & 51.6 & 71.6 & 89.6 & 91.6 & 5 & 1.7 \\
\hline & \multicolumn{2}{|c|}{$\mathrm{H}_{2} \mathrm{O}_{2}$-bleaching } & 123.1 & 126.9 & 92.8 & 92.9 & -8.8 & -9.5 \\
\hline
\end{tabular}

Table 2 shows the results of color measurements of cotton fabrics treated by enzymatic CPB pretreatment and each company's conventional chemical CPB pretreatment in industrial scale. Whiteness, lightness and b-values were focused among color measurement parameters. Bigger values in whiteness and $\mathrm{L}$ represent lighter and whiter while bigger $b$ values mean yellowness of fabric. When values of final fabrics biopretreated were compared to those pretreated conventionally, subsequent dyeing of bio-pretreated fabrics is expected to give as reproducible results as those pretreated conventionally regardless of paleto deep shade dyeing both in industrial trial No. 1 and No. 2.

\section{Conclusion}

Industrial trials on bio-pretreatment of $100 \%$ cotton and cotton-blend woven fabrics by cold-pad-batch methods using the combination of amylase of low temperature type for desizing and alkaline pectinase for scouring gave the satisfactory results in water absorption and whiteness of pretreated cotton fabrics as well as the homogeneity of water absorption across the 1000 yards of fabric length. These results allow textile dyeing companies to use their existing CPB facilities for the introduction of new enzymatic pretreatment process substituting for a conventional strong alkaline process while maintaining their production capacity.

\section{Acknowledgements}

Authors appreciate the technical cooperation of $\mathrm{K}$ Textile Co., Ltd and CW Textile Co., Ltd in running industrial scale biopretreatment process. 


\section{Current Trends in Fashion Technology \& Textile Engineering}

\section{Conflict of Interest}

The authors report no conflicts of interest. The authors alone are responsible for the content and writing of the paper.

\section{References}

1. Wakelyn PJ (2007) Cotton Fiber Chemistry and Technology. CRC Press, Boca Raton, USA, pp. 28-30.

2. Karmakar SR (1999) Chemical Technology in the Pre-Treatment Processes of Textiles. Elsevier Science Amsterdam BV (Ed.), the Netherlands 72: pp. 86-90.

3. Hardin JR (2010) Chapter 6. Enzymatic treatment versus conventional chemical processing of cotton. In: Nierstrasz VA, Cavaco-Paulo A (Eds.), Advances in Textile Biotechnology, Woodhead Publishing Limited, Cambridge, UK.

4. Mielicha E (2011) Types and suitability of yarns for knitting. In: Au KF (Ed.), Advances in Knitting Technology. Woodhead Publishing Limited, Cambridge, UK, pp.10-11.

5. Gordon R (2006) The preparation, dyeing and finishing of cotton knit goods, Nearchimica $\mathrm{SpA}$, Legnano, Italy.

6. Lacasse K, Baumann W (2004) Textile Chemicals: Environmental Data and Facts. Springer-Verlag, Berlin Heidelberg, Germany. pp. 506.

7. Ibrahim DF (2012) Sustainable line of cotton wet processing. J Textile Sci Eng 3(1): 1-3.
8. Aehle W (2007) Enzymes in Industry: Production and Applications. ( $3^{\text {rd }}$ Edn), Wiley-VCH Verlag, Weinheim, Germany, pp. 218-221.

9. Agrawal BJ (2017) Bio-stoning of denim- an environmental-friendly approach. Curr Trends Biomedical Eng \& Biosci 3(3): 1-3.

10. Blackburn RS (2009) Sustainable Textiles: Life Cycle and Environmental Impact. Woodhead Publishing Limited, Cambridge, UK, pp.135-138.

11. Choe EK, Nam CW, Kook SR, Chung C, Cavaco-Paulo A (2004) Implementation of batchwise bioscouring of cotton knits. Biocatal Biotransformation 22(5/6): 375-382.

12. Kim J, Kim SY, Choe, EK (2006) The beneficial influence of enzymatic scouring on cotton properties. J Nat Fibers 2(4): 39-52.

13. Wang Q, Fan X, Gao W, Chen J (2006) Characterization of bioscoured cotton fabrics using FT-IR ATR spectroscopy and microscopy techniques. Carbohydr Res 341(12): 2170-2175.

14. https://www.wateractionplan.com/documents/186210/186332/ Best+Technology_Cold+Pad+Batch.pdf

15. Technical Information (2000) Pretreatment of cotton via cold-padbatch. BASF.

16. Choe EK, Park JH, Kim SD (2005) Bioscouring of 100\% cotton fabric with alkaline pectinase. J Korean Soc Dyers \& Finishers 17(1): 14-19.

\begin{tabular}{|l|}
\hline \multicolumn{1}{|c|}{ Your next submission with Juniper Publishers } \\
will reach you the below assets \\
- Quality Editorial service \\
- Swift Peer Review \\
- Reprints availability \\
- E-prints Service \\
- Manuscript Podcast for convenient understanding \\
- Global attainment for your research \\
- Manuscript accessibility in different formats \\
( Pdf, E-pub, Full Text, Audio) \\
- Unceasing customer service \\
Track the below URL for one-step submission \\
https://juniperpublishers.com/online-submission.php \\
\hline
\end{tabular}

